\title{
Exposure and health impacts of outdoor particulate matter in two urban and industrialized area of Tabriz, Iran
}

\author{
Akbar Gholampour ${ }^{1,2}$, Ramin Nabizadeh ${ }^{1}$, Simin Naseri ${ }^{1,3}$, Masud Yunesian ${ }^{4}$, Hasan Taghipour ${ }^{2}$, Noushin Rastkari ${ }^{4}$,
} Shahrokh Nazmara ${ }^{1}$, Sasan Faridi ${ }^{1}$ and Amir Hossein Mahvi ${ }^{1,5,6^{*}}$

\begin{abstract}
Numerous studies have shown associations between air pollution and health effects on human. The aims of the present study were to provide quantitative data on variation of atmospheric particulate matter (PM) concentration and the impact of PM on the health of people living in Tabriz city. The approach proposed by the World Health Organization (WHO) was applied using the AirQ 2.2.3 software developed by the WHO European Centre for Environment and Health, Bilthoven Division. The concentration of particulate matter were measured at urban and industrial suburban sites in Tabriz, Iran, from September 2012 to June 2013. TSP and PM 10 samples were collected using high volume samplers. $\mathrm{PM}_{2.5}$ and $\mathrm{PM}_{1}$ were measured by Haz-Dust EPAM-5000 particulate air monitors. The annual average concentrations of TSP, $\mathrm{PM}_{10}, \mathrm{PM}_{2.5}$, and $\mathrm{PM}_{1}$ in the urban site were $142.2 \pm 76.3,85.3 \pm 43.9,39 \pm$ 19.1 , and $28.4 \pm 14.9 \mathrm{\mu g} / \mathrm{m}^{3}$ (mean $\pm \mathrm{SD}$ ), respectively. Also in industrial suburban, the total average concentrations of TSP, PM $10, \mathrm{PM}_{2.5}$, and $\mathrm{PM}_{1}$ were measured as $178.7 \pm 52.7,109.9 \pm 30.2,40.0 \pm 10.9$, and $31.4 \pm 9.1 \mathrm{\mu g} / \mathrm{m}^{3}$, respectively. The $\mathrm{PM}_{10}$ /TSP ratio for the whole study period ranged between 0.35-0.91 and 0.32-0.79 in the urban and suburban sites, respectively. Total mortalities associated with TSP, $\mathrm{PM}_{10}$ and $\mathrm{PM}_{2.5}$ concentrations were 327, 363, and 360, respectively. Furthermore, the cardiovascular mortalities for TSP and PM $_{10}$ were 202 and 227 individual, respectively. According to the attributable respiratory mortalities of 99 and 67 associated respectively with TSP and $\mathrm{PM}_{10}$, it is clear that cardiovascular mortality resulted from PM might attributed to total mortality. The maximum 24-hour concentration of PM was observed during winter followed by autumn and the lowest one was during spring.
\end{abstract}

Keywords: Air pollution, Particulate matter, Health impact assessment, AirQ software

\section{Introduction}

Industrialization, urbanization and increasing of population are resulting in the pollution of environment $[1,2]$. Deterioration of urban air quality has become an increasing and widespread concern in both developed and developing communities [3-5]. Among air pollutant, particulate matter $(\mathrm{PM})$ is the pollutant with the most undesired health effects [6]. The most important effects of air pollution on human health have been attributed to the existence of PM at high levels. Not only it does

\footnotetext{
* Correspondence: ahmahvi@yahoo.com

'Department of Environmental Health Engineering, School of Public Health,

Tehran University of Medical Sciences, Tehran, Iran

${ }^{5}$ Center for Solid Waste Research (CAPR), Institute for Environmental

Research, Tehran University of Medical Sciences, Tehran, Iran

Full list of author information is available at the end of the article
}

lead to an increased mortality $[7,8]$ and the number of hospital admissions due to different causes; the amount of Quality Adjusted Life Years (QALYs) lost as a consequence of exposure to such particles is estimated by the WHO around 6.4 million per year [9]. Also, it has been shown that heart and respiratory diseases are hazardously affected with environmental particulate matter $[7,8,10]$.

Generally, the fine particulate fraction of total suspended particulates (TSP) (i.e., $\mathrm{PM}_{2.5}$ ) arises from combustion processes. On the other hand, the coarser fraction (i.e., $\mathrm{PM}_{10}$ ) originates from mechanical and re-suspension processes [11]. The deposition of PM at different regions of respiratory system directly depends on particles' size [12]. While $\mathrm{PM}_{10}$ have been associated with respiratory hospital

\section{Biomed Central}

(c) 2014 Gholampour et al.; licensee BioMed Central Ltd. This is an open access article distributed under the terms of the Creative Commons Attribution License (http://creativecommons.org/licenses/by/2.0), which permits unrestricted use, distribution, and reproduction in any medium, provided the original work is properly cited. 
admissions [6,13], $\mathrm{PM}_{2.5}$ have been more strongly correlated with both mortality and morbidity $[14,15]$. Therefore, $\mathrm{PM}_{2.5}$ have received more attentions in recent years due to its stronger ability in developing adverse health impacts $[8,16,17]$.

Pope and Dockery summarized evaluations of health effects associated with long- and short-term exposures to ambient PM conducted in recent year; where shortterm is referring to 24-hr exposure [8]. They reported that $\mathrm{PM}_{10}$ is associated with all-cause mortality, lung cancer, and nonmalignant respiratory mortality for males and coronary heart disease in females [7]. Several studies have focused on the mass concentrations, health impacts, chemical characterization, and source identification of PM and also dust storm in some cities of Iran [18-23]. However, to the best of our knowledge, there are limited published studies, which have dealt with mass concentrations and health impact assessment of PM in Tabriz [24].

Tabriz (Figure 1) is the capital city of East Azerbaijan province. It is one of the largest urban areas in Iran with approximately 1.7 million population in 2012 and total surface area of $320 \mathrm{~km}^{2}$ [25]. There are some light and heavy industries located on the Northwestern, Western, and Southwestern of this city. Industries such as oil refinery, thermal power plant, and petrochemical complex have been located on the Southwestern, while a cement factory has been situated on the Northwestern fringe of the city. In recent years, because of development of industries and also increase in the number of vehicles in urban area, Tabriz has faced with serious air pollution problems, especially in winter season [24]. In addition, the air pollution in Tabriz is mostly under the influence of atmospheric thermal inversion in cold season and moreover recently the Middle East dust storm (originating from Iraq) in the warm season exacerbated the air pollution in this area [24].

The present study was therefore carried out to determine the mass levels of (TSP), $\mathrm{PM}_{10}, \mathrm{PM}_{2.5}$, and $\mathrm{PM}_{1}$ along with the seasonal variations of PM in Tabriz. The other aim of this study was to estimate health impacts of TSP, $\mathrm{PM}_{10}$ and $\mathrm{PM}_{2.5}$ using AirQ software developed by World Health Organization (WHO).

\section{Materials and methods}

\section{Sampling sites and schedule}

Two sites were selected based on their different land use categories: (1) the urban site, located near the center of city in a residential region $\left(38^{\circ} 3^{\prime} 18.08^{\prime \prime} \mathrm{N}, 46^{\circ} 19^{\prime}\right.$ $22.77^{\prime \prime}$ E), with the distance about $200 \mathrm{~m}$ from major street and $1000 \mathrm{~m}$ away from a main freeway [26]. The samplers were operated on the roof of a three-stories building at the height of 15 meters above ground level. Samples were collected on every six day throughout the sampling period [27], from September 2012 to June 2013. (2) An industrial suburban site situated out of the urban border, approximately $1000 \mathrm{~m}$ away from a major freeway and $500 \mathrm{~m}$ from the main street $\left(38^{\circ} 4^{\prime} 23.98^{\prime \prime} \mathrm{N}, 46^{\circ} 9^{\prime}\right.$ $\left.35.55^{\prime \prime} \mathrm{E}\right)$. A petroleum refinery, a small industrial estate, a thermal powerhouse, and some other small industrial plants were located adjacent to the industrial sampling site. The samplers were operated on the height of 3 meters above the ground level. About 3 to 4 samples were collected in every month during the November 2012 to
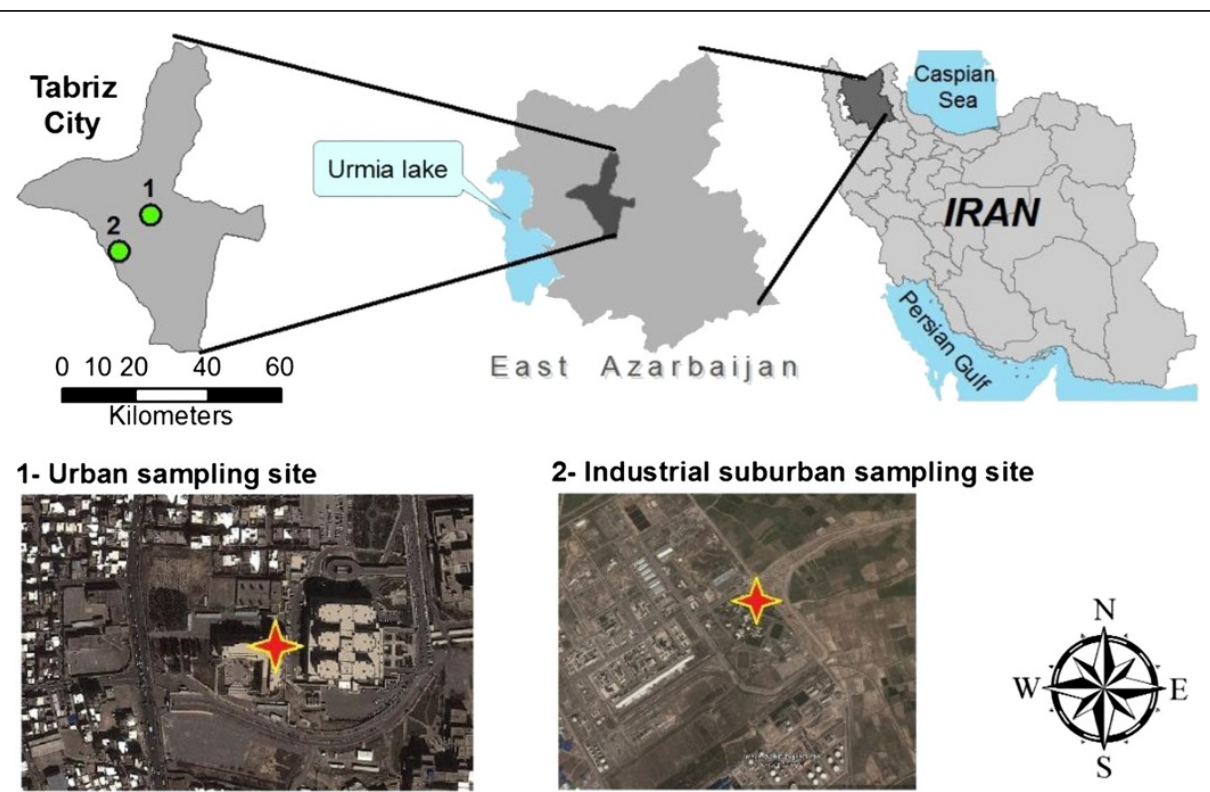

2- Industrial suburban sampling site
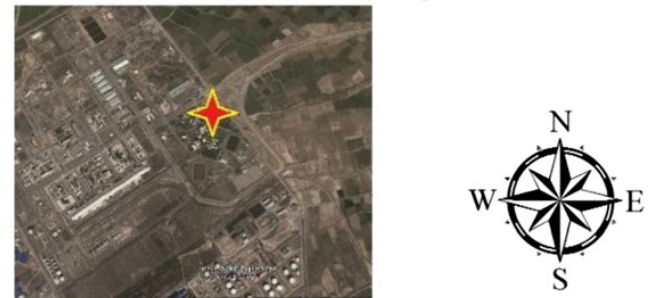

Figure 1 Location of study area and sampling sites. 
May 2013 [27]. The location of sampling stations is shown in Figure 1.

\section{PM measurement}

Samples of TSP, $\mathrm{PM}_{10}, \mathrm{PM}_{2.5}$, and $\mathrm{PM}_{1}$ were simultaneously collected during the study period. TSP and $\mathrm{PM}_{10}$ samples $(\mathrm{n}=80)$ were collected by two high volume (hi-vol.) samplers (Graseby-Andersen) at flow rates of $1.13-1.41 \mathrm{~m}^{3} / \mathrm{min}$ for $24 \mathrm{~h}$. Both TSP and $\mathrm{PM}_{10}$ were collected on a $20.3 \mathrm{~cm} \times 25.4 \mathrm{~cm}$ Whatman glass micro fiber filters. All filters were maintained at conditions of $40 \%$ relative humidity $(\mathrm{RH})$ and $25^{\circ} \mathrm{C}$ for over $48 \mathrm{~h}$, afterward at the room condition for $2 \mathrm{~h}$ and then were weighted before sampling. After collection of PM samples, the filters were treated in the same conditions, which mentioned for preparation of filters and then were weighed using an A\&D electronic balance (Model GR-300) with the reading precision of $0.1 \mathrm{mg}$.

$\mathrm{PM}_{2.5}$ and $\mathrm{PM}_{1.0}(\mathrm{n}=80)$ were measured by means of two portable HAZ-DUST EPAM-5000 particulate air monitors at the flow rate of $2.5-3 \mathrm{~L} / \mathrm{min}$. The Haz-Dust had been calibrated using Arizona Road Dust (ARD) against $\mathrm{NIOSH}$ method 0600 for inhaling dust with $\mathrm{a} \pm$ $10 \%$ accuracy in the factory. Also, the span reference was used as a reference to check factory calibration of the EPAM-5000 Monitor.

\section{Meteorological data}

Wind speed, wind direction, ambient air temperature, atmospheric visibility, and $\mathrm{RH}$ at sampling stations were obtained from the national climatic data center (NCDC) [28] and East Azerbaijan Meteorological Organization. The obtained data were examined for the missing values and outliers to input in WRPLOT View Freeware 7.0.0 to plot the wind rose and also in Microsoft Excel 2010 to plot the temporal trends for the other parameters.

\section{Data analysis}

Descriptive statistics were used to explain the obtained results. The concentrations of PM were analyzed using Microsoft Excel 2010. Hourly and daily average concentrations were calculated from $30 \mathrm{~min}$ data. The mortality and morbidity rates associated with the TSP, $\mathrm{PM}_{10}$, and $\mathrm{PM}_{2.5}$ concentrations were estimated by AirQ software Ver.2.2.3, which was developed by WHO European Centre for Environment Health [29].

AirQ software was used to estimate the effect of exposure to specific atmospheric pollutants (PM effect in this study) on the health of people living in a certain period and area. The estimation is based on the attributable proportion (AP), defined as the fraction of the health impact in a certain population attributable to the exposure to a given atmospheric pollutant. The formula used for calculation of AP is [30]:

$$
\mathrm{AP}=\frac{\sum\{[\operatorname{RR}(\mathrm{c})-1] \times \mathrm{P}(\mathrm{c})\}}{\sum[\mathrm{RR}(\mathrm{c}) \times \mathrm{P}(\mathrm{c})]}
$$

where:

AP is the attributable proportion of the health impact,

$R R$ is the relative risk for a given health impact, in category "C" of exposure which can be obtained from the exposure to response functions derived from epidemiological researches and

$\mathrm{P}(\mathrm{c})$ is the amount of population in category " $\mathrm{C}$ ".

If the baseline incidence of health impact in the population under study is known, the attributable rate to the exposure can be calculated from following formula:

$$
\mathrm{IE}=\mathrm{I} \times \mathrm{AP}
$$

where:

IE is the rate of the health impact attributable to the exposure, and

I is the baseline incidence of health outcome in the population under study.

Finally, knowing the total number of population, the amount of cases attributable to the exposure can be estimated as:

$$
\mathrm{NE}=\mathrm{IE} \times \mathrm{N}
$$

where:

NE is the amount of cases attributed to the exposure, and

$\mathrm{N}$ is the total number of investigated population.

The RR values used for TSP analysis were derived from the study of Chen et al. [31] and Goldberg et al. [32], while in the case of $\mathrm{PM}_{10}$, this parameter was obtained from a quantitative meta-analysis by Anderson et al. [33] and also adopted from the study of Breitner et al. [34] and finally a summary estimate in the WHO Air Quality Guidelines for Europe [35] was used for estimating of $\mathrm{PM}_{2.5}$ induced health effects.

In this study, exposure was estimated considering the city of Tabriz with a residential population of about $1,700,000$ people.

\section{Results and discussion}

The variations of meteorological data including ambient air temperature, atmospheric visibility, precipitation, and wind speed during the study period are shown in Figure 2. Based on the collected data at present study, January was the coldest month with the mean temperature of $-3^{\circ} \mathrm{C}$, while July was the warmest month with the mean temperature of $38^{\circ} \mathrm{C}$. Also the $\mathrm{RH}$ varied from $15 \%$ to $87 \%$. Seasonal wind rose plots (Figure 3 ) show 


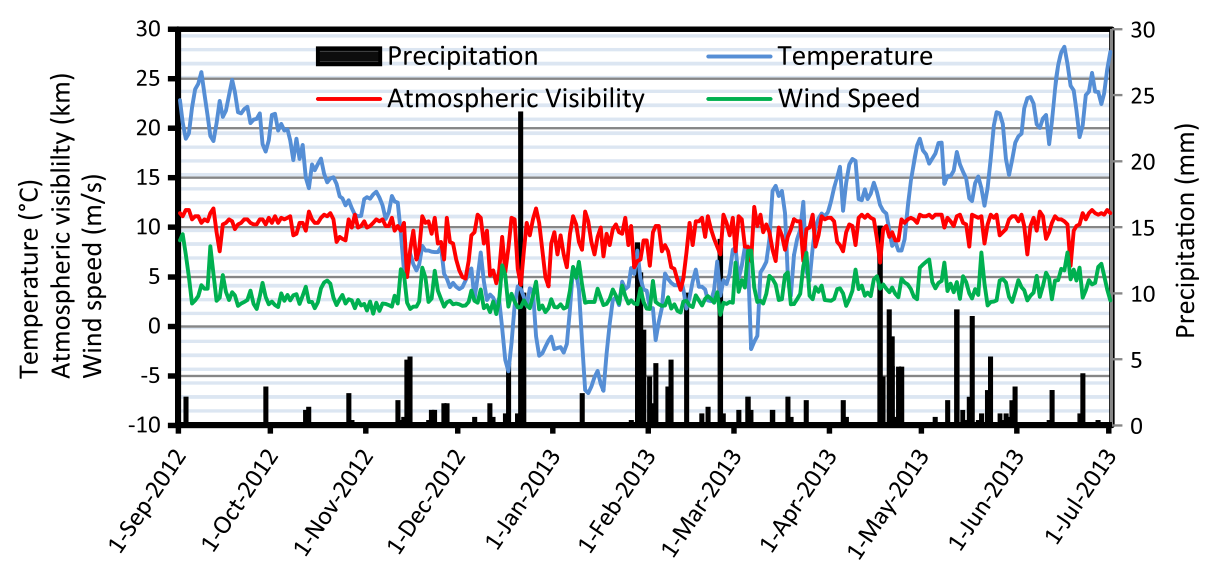

Figure 2 The trend of daily average for ambient temperature, visibility, wind speed, and precipitation in Tabriz.

that autumn and winter, with the mean wind speeds of 3.12 and $3.08 \mathrm{~m} / \mathrm{s}$, respectively, were relatively the calm seasons compared with summer $(5.14 \mathrm{~m} / \mathrm{s})$ and spring $(4.57 \mathrm{~m} / \mathrm{s})$. The prevailing wind blew from the Northeast with the speed varied from 0.5 to $11.5 \mathrm{~m} / \mathrm{s}$. The annual mean wind speed was $4.01 \mathrm{~m} / \mathrm{s}$. Calm wind $(0 \mathrm{~m} / \mathrm{s})$ frequencies were $5.3 \%, 1.8 \%, 11.5 \%$, and $9.35 \%$ in spring, summer, autumn and winter, respectively.

In this study, total of 160 samples in the urban and 60 samples in the industrial suburban were collected. Descriptive statistics of mass concentrations of the PM are presented in Table 1 . The annual average concentrations of TSP, $\mathrm{PM}_{10}, \mathrm{PM}_{2.5}$, and $\mathrm{PM}_{1}$ in the urban sampling site were $142.2 \pm 76.3,85.3 \pm 43.9,39 \pm 19.1$, and $28.4 \pm 14.9 \mu \mathrm{g} / \mathrm{m}^{3}$, respectively. The percentage of days that 24-h mean concentrations of $\mathrm{PM}_{10}$ and $\mathrm{PM}_{2.5}$ exceeded WHO guideline [36] and national standard level $\left(50 \mu \mathrm{g} / \mathrm{m}^{3}\right.$ for $\mathrm{PM}_{10}$ and $25 \mu \mathrm{g} / \mathrm{m}^{3}$ for $\left.\mathrm{PM}_{2.5}\right)$ in the cold months were considerably higher than the warm months. Due to weather conditions, decrease of temperature, and higher frequency of calm wind, which led to thermal inversion in cold months (especially October, January, and February), together increase in the use of fuel for heating devices in homes and trafficrelated combustion processes resulting in the increase of PMs' mass concentration. The highest concentration of PM was observed during winter followed by autumn and the lowest concentration was during spring. The obtained results show that the measured maximum diurnal mass concentration of TSP $\left(480.4 \mu \mathrm{g} / \mathrm{m}^{3}\right)$ occurred in the 7th January (in this study) while in the case of $\mathrm{PM}_{10}$, maximum diurnal mass concentration $\left(230.0 \mu \mathrm{g} / \mathrm{m}^{3}\right)$ was observed in 14th January. In addition, the maximum daily mass concentration of $\mathrm{PM}_{2.5}\left(96.6 \mu \mathrm{g} / \mathrm{m}^{3}\right)$ and $\mathrm{PM}_{1}$ $\left(72.2 \mu \mathrm{g} / \mathrm{m}^{3}\right)$ were detected in February.

The international convention that has been used defining dust storm intensity is based on ambient air wind speeds and the reduction of atmospheric visibility [37]. In this study, system introduced by Hoffmann et al. [35] in combination with atmospheric visibility and ambient air wind speed were used to determine dust storm entrance to the study region and also to classify the intensity of dust storm, i.e. "(sand-) dust storms" with wind speeds $17 \mathrm{~m} / \mathrm{s}$ and visibility $1000 \mathrm{~m}$, "strong (sand-) dust storms" with wind speeds $20 \mathrm{~m} / \mathrm{s}$ and visibility 200 $\mathrm{m}$ and "serious strong (sand-) dust storms" with wind speeds $25 \mathrm{~m} / \mathrm{s}$ and visibility $50 \mathrm{~m}$. Based on this classification and continual fine-dust measurements, an extended classification was proposed and extended by two classes based on the content of $\mathrm{PM}_{10}$ as follows: "Dusty

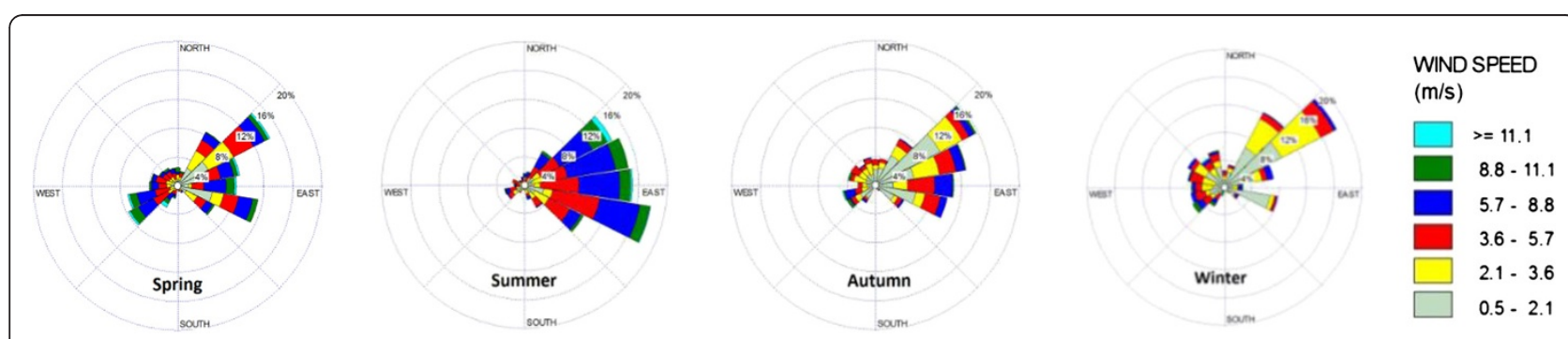

Figure 3 Seasonal wind rose plots during the study period in Tabriz (2012-2013). 
Table 1 Descriptive statistics for the 24-hour PM mass concentrations $\left(\mu \mathrm{g} / \mathrm{m}^{3}\right)$ in the urban and suburban sampling sites

\begin{tabular}{|c|c|c|c|c|c|c|c|c|c|c|c|c|c|}
\hline \multirow[t]{2}{*}{ PM } & \multicolumn{7}{|c|}{ Urban sampling site } & \multicolumn{6}{|c|}{ Suburban sampling site } \\
\hline & Month & Average & SD & Min & Max & Median & $\begin{array}{l}\% \text { exceed from } \\
\text { standard level }\end{array}$ & Average & SD & Min & Max & Median & $\begin{array}{c}\% \text { exceed from } \\
\text { standard level }\end{array}$ \\
\hline \multirow[t]{11}{*}{ TSP } & September & 143.4 & 60.4 & 67.9 & 227.6 & 146.4 & - & - & - & - & - & - & - \\
\hline & October & 209.8 & 71.8 & 113.1 & 313.2 & 209.8 & - & - & - & - & - & - & - \\
\hline & November & 70.5 & 65.2 & 26.5 & 183.2 & 37.9 & - & 204.9 & 11.4 & 191.8 & 212.8 & 210.00 & - \\
\hline & December & 112.0 & 36.1 & 76.4 & 169.9 & 112.0 & - & 193.4 & 21.0 & 171.5 & 213.3 & 195.40 & - \\
\hline & January & 184.5 & 98.6 & 104.7 & 480.4 & 155.1 & - & 219.5 & 61.4 & 154.5 & 276.5 & 227.45 & - \\
\hline & February & 178.4 & 55.2 & 101.5 & 255.6 & 178.4 & - & 148.1 & 21.1 & 130.4 & 171.4 & 142.50 & - \\
\hline & March & 139.5 & 66.5 & 78.6 & 251.7 & 119.9 & - & 86.6 & 26.0 & 56.9 & 105.5 & 97.49 & - \\
\hline & April & 97.8 & 34.1 & 45.7 & 138.9 & 97.7 & - & 183.9 & 10.6 & 173.7 & 194.9 & 183.10 & - \\
\hline & May & 93.5 & 10.9 & 75.6 & 105.6 & 95.5 & - & 214.3 & 47.3 & 162.6 & 255.3 & 224.99 & - \\
\hline & June & 102 & 36.6 & 65.8 & 134.4 & 98.5 & - & - & - & - & - & - & - \\
\hline & Overall & 142.2 & 76.3 & 26.5 & 480.4 & 127.5 & - & 178.7 & 52.7 & 56.9 & 276.5 & 183.0 & - \\
\hline \multirow[t]{11}{*}{$\mathrm{PM}_{10}$} & September & 84.9 & 40.0 & 38.2 & 147.8 & 86.2 & 67 & - & - & - & - & - & - \\
\hline & October & 129.5 & 48.3 & 62.7 & 197.1 & 129.5 & 100 & - & - & - & - & - & - \\
\hline & November & 44.2 & 41.2 & 14.9 & 115.3 & 24.5 & 20 & 142.4 & 13.3 & 131.1 & 157.1 & 139.06 & 100 \\
\hline & December & 84.3 & 21.9 & 65.5 & 121.2 & 79.6 & 100 & 115.1 & 10.9 & 103.3 & 124.6 & 117.42 & 100 \\
\hline & January & 109.7 & 33.0 & 67.4 & 230.0 & 97.4 & 100 & 106.2 & 17.3 & 87.5 & 121.8 & 109.40 & 74 \\
\hline & February & 106.2 & 40.6 & 56.0 & 167.2 & 106.2 & 100 & 111.2 & 21.7 & 98.4 & 136.3 & 98.85 & 100 \\
\hline & March & 95.1 & 46.9 & 50.5 & 174.0 & 80.2 & 80 & 53.1 & 14.4 & 36.7 & 63.8 & 58.80 & 35 \\
\hline & April & 44.2 & 15.8 & 21.3 & 65.9 & 44.2 & 20 & 134.2 & 9.7 & 125.4 & 144.5 & 132.80 & 100 \\
\hline & May & 43.3 & 9.8 & 33.1 & 58.5 & 40.6 & 40 & 106.9 & 19.1 & 85.6 & 122.5 & 112.72 & 100 \\
\hline & June & 47.2 & 18.5 & 30.6 & 71.3 & 49.0 & 25 & - & - & - & - & - & - \\
\hline & Overall & 85.2 & 43.9 & 14.9 & 197.1 & 82.3 & 72 & 109.9 & 30.2 & 36.7 & 157.1 & 108.9 & - \\
\hline \multirow[t]{11}{*}{$\mathrm{PM}_{2.5}$} & September & 38.7 & 18.2 & 18.6 & 65.2 & 38.8 & 67 & - & - & - & - & - & - \\
\hline & October & 55.5 & 18.8 & 25.6 & 75.3 & 55.5 & 80 & - & - & - & - & - & - \\
\hline & November & 22.8 & 14.0 & 12.0 & 46.8 & 18.0 & 20 & 43.5 & 6.5 & 36.8 & 49.7 & 44.02 & 100 \\
\hline & December & 41.3 & 22.2 & 15.0 & 76.0 & 41.0 & 80 & 44.9 & 6.4 & 40.5 & 52.3 & 42.00 & 100 \\
\hline & January & 47.7 & 14.0 & 31.7 & 79.0 & 43.2 & 100 & 38.7 & 12.9 & 23.9 & 46.8 & 45.48 & 82 \\
\hline & February & 53.0 & 25.3 & 35.1 & 96.6 & 42.4 & 100 & 47.2 & 9.4 & 38.6 & 57.3 & 45.60 & 100 \\
\hline & March & 40.2 & 12.5 & 23.1 & 56.4 & 41.8 & 80 & 21.6 & 5.6 & 15.6 & 26.7 & 22.42 & 44 \\
\hline & April & 23.8 & 7.6 & 13.5 & 34.7 & 23.3 & 40 & 48.9 & 2.5 & 46.4 & 51.4 & 48.90 & 100 \\
\hline & May & 20.0 & 5.0 & 13.4 & 25.4 & 21.5 & 20 & 35.2 & 3.1 & 32.2 & 38.5 & 34.81 & 87 \\
\hline & June & 24.1 & 6.5 & 15.9 & 38.4 & 24.7 & 30 & - & - & - & - & - & - \\
\hline & Overall & 39.0 & 19.1 & 12.0 & 96.6 & 36.6 & 71 & 40.0 & 10.9 & 15.6 & 57.3 & 41.6 & - \\
\hline \multirow[t]{8}{*}{$\mathrm{PM}_{1}$} & September & 24.1 & 13.1 & 10.6 & 45.9 & 23.1 & - & - & - & - & - & - & - \\
\hline & October & 30.6 & 9.3 & 15.6 & 40.6 & 30.6 & - & - & - & - & - & - & - \\
\hline & November & 14.6 & 6.7 & 8.7 & 25.6 & 14.0 & - & 37.2 & 5.9 & 30.8 & 42.3 & 38.64 & - \\
\hline & December & 32.7 & 18.3 & 11.3 & 60.0 & 32.7 & - & 34.6 & 2.5 & 31.8 & 36.4 & 35.65 & - \\
\hline & January & 40.3 & 10.8 & 28.0 & 66.0 & 37.8 & - & 30.2 & 10.4 & 18.9 & 39.3 & 32.54 & - \\
\hline & February & 40.5 & 18.9 & 23.2 & 72.2 & 35.7 & - & 37.9 & 7.9 & 31.6 & 46.8 & 35.38 & - \\
\hline & March & 28.3 & 10.8 & 14.9 & 43.1 & 28.3 & - & 16.6 & 2.8 & 13.4 & 18.9 & 17.45 & - \\
\hline & April & 18.3 & 7.5 & 9.5 & 30.3 & 17.8 & - & 37.2 & 5.8 & 31.7 & 43.3 & 36.52 & - \\
\hline
\end{tabular}


Table 1 Descriptive statistics for the 24-hour PM mass concentrations $\left(\mu \mathrm{g} / \mathrm{m}^{3}\right)$ in the urban and suburban sampling sites (Continued)

\begin{tabular}{cccccccccccccc}
\hline May & 13.2 & 3.1 & 9.6 & 17.3 & 13.0 & - & 25.7 & 3.3 & 23.5 & 29.6 & 24.15 & - \\
June & 22.3 & 5.5 & 12.6 & 25.8 & 20.5 & - & - & - & - & - & - & - \\
Overall & 28.4 & 14.9 & 8.7 & 72.2 & 28.6 & - & 31.4 & 9.1 & 13.4 & 46.8 & 31.5 & - \\
\hline
\end{tabular}

Air" with an hourly average of $\mathrm{PM}_{10}$ higher than $50 \mu \mathrm{g} / \mathrm{m}^{3}$ according to the European limit value for $\mathrm{PM}_{10}$ and "Light Dust Storm" with an hourly average of $\mathrm{PM}_{10}$ higher than $200 \mu \mathrm{g} / \mathrm{m}^{3}$ (Table 2) [38].

Based on obtained meteorological data, the minimum atmospheric visibility was $3700 \mathrm{~m}$ that occurred in 11th February. In this day, mean wind speed of ambient air was $1.4 \mathrm{~m} / \mathrm{s}$ and the concentration of $\mathrm{PM}_{10}$ was equal to $167.24 \mu \mathrm{g} / \mathrm{m}^{3}$. It is therefore clear from Tables 1 and 2 and also Figure 2, that during the present study, dust storm did not consider at the studied region.

In order to determination of local dust emission, it was assumed that increased dust concentrations during strong winds under non supra regional dust storm conditions would indicate the emission of local dust into the study area [38]. Based on this definition and with respect to the wind speed $(6.1 \mathrm{~m} / \mathrm{s})$, atmospheric visibility $(4200 \mathrm{~m})$, and also high concentration of TSP and $\mathrm{PM}_{10}$ at 7 th January, it could be concluded that on this date, local dust occurred.

In the industrial suburban, the overall average of TSP, $\mathrm{PM}_{10}, \mathrm{PM}_{2.5}$, and $\mathrm{PM}_{1}$ mass concentrations were $178.7 \pm$ $52.7,109.9 \pm 30.2,40.0 \pm 10.9$, and $31.4 \pm 9.1 \mu \mathrm{g} / \mathrm{m}^{3}$, respectively. Due to the nature of industrial activities in this section and their full time work, the variation of PMs' concentrations could not be related to the monthly trend and is mainly affected by the type and the quantity of industries' production along with the duration of those activities. Because of the Iranian New Year holidays in March and hence decline in the manufacturing activity and also increase of rainfall, the values of PM decreased significantly in corresponding days. Among days that the ambient air PM has been measured (based on sampling schedule) and also based on obtained meteorological data only at 7th January local dust occurred.

Table 3 represents the ratio of PMs' species in the urban and industrial suburban sampling sites. The average

Table 2 Dust storm classification (based on $\mathrm{PM}_{10}$ concentration) $[37,38]$

\begin{tabular}{lccc}
\hline Category & Visibility $(\mathbf{m})$ & Wind speed $(\mathbf{m} / \mathbf{s})$ & $\mathbf{P M}_{\mathbf{1 0}}\left(\boldsymbol{\mu g} / \mathbf{m}^{\mathbf{3}}\right)$ \\
\hline Dusty air & haze & - & $50-200$ \\
Light dust storm & $<2000$ & - & $200-500$ \\
Dust storm & $<1000$ & $>17$ & $500-2000$ \\
Strong dust storm & $<200$ & $>20$ & $2000-5000$ \\
Serious strong DS & $<50$ & $>25$ & $>5000$ \\
\hline
\end{tabular}

of $\mathrm{PM}_{2.5} / \mathrm{PM}_{10}$ ratio in the urban site (0.48) was higher than those for suburban (0.38). It might be due to the higher traffic jams in Tabriz city mixed with the emission from the nearby residential area. The $\mathrm{PM}_{10} / \mathrm{TSP}$ ratio for the whole study period ranged between 0.35 0.91 and $0.32-0.79$ in the urban and suburban sites, respectively.

Because of significant differences in particle sources and also other geographical and meteorological conditions, the obtained results from one study cannot be directly compared with the findings of other researches. However, the results of some researches in the other countries were studied and compared with the results of the present study. Other studies found that the $\mathrm{PM}_{10} / \mathrm{TSP}$ ratio in high polluted urban regions was $0.4-0.8$, whereas this ratio in rural and suburban sites ranged 0.57 - 0.62 [39-41]. As it can be seen, the range of $\mathrm{PM}_{10} / \mathrm{TSP}$ ratio in our study was wider than other researches.

Figure 4 shows the mean hourly variations of $\mathrm{PM}_{10}$, $\mathrm{PM}_{2.5}$, and $\mathrm{PM}_{1}$ in both sampling sites. As it can be seen in Figure 4, the hourly variations of $\mathrm{PM}_{10}, \mathrm{PM}_{2.5}$, and $\mathrm{PM}_{1}$ in urban site have almost an identical behavior and clearly governed by the road traffic pattern. Different patterns were observed for $\mathrm{PM}_{10}, \mathrm{PM}_{2.5}$, and $\mathrm{PM}_{1}$ in suburban sampling site compared with the urban site. This difference could be due to the 24-hour working of industries.

High maximum hourly $\mathrm{PM}_{2.5}$ and $\mathrm{PM}_{1}$ levels at 8 to $12 \mathrm{AM}$ in urban could be due to beginning of daily work and the increased traffic of vehicles. The highest values of $\mathrm{PM}_{10}, \mathrm{PM}_{2.5}$, and $\mathrm{PM}_{1}$ in suburban site did not show a certain pattern.

Figure 5 shows the air quality index (AQI) values for $\mathrm{PM}_{10}$ and $\mathrm{PM}_{2.5}$ concentrations in Tabriz during sampling period. The high $\mathrm{PM}_{10}$ concentrations during the October and January produced AQI values over 100. The maximum AQI value calculated for $\mathrm{PM}_{10}$ was 122 (for eighth October). These values imply that the air is unhealthy for sensitive groups and may cause the aggravation of cardiovascular and respiratory diseases, increase premature mortality in sensitive groups, and increase hospital admissions for respiratory diseases in the general population. The AQI values for the other days were lower and in the most of sampling days in cold seasons (especially in the winter) were between 50 and 100. These values represent moderate health concern for a very small number of people [42]. 
Table 3 The ratio ${ }^{a}$ of PMs' species in the urban and industrial suburban site

\begin{tabular}{|c|c|c|c|c|c|c|c|c|}
\hline & \multicolumn{4}{|c|}{ Urban sampling site } & \multicolumn{4}{|c|}{ Industrial suburban sampling site } \\
\hline & $\mathrm{PM}_{10} / \mathrm{TSP}$ & $\mathrm{PM}_{2.5} / \mathrm{PM}_{10}$ & $\mathrm{PM}_{1} / \mathrm{PM}_{10}$ & $\mathrm{PM}_{1} / \mathrm{PM}_{2.5}$ & $\mathrm{PM}_{10} / \mathrm{TSP}$ & $\mathrm{PM}_{2.5} / \mathrm{PM}_{10}$ & $\mathrm{PM}_{1} / \mathrm{PM}_{10}$ & $\mathrm{PM}_{1} / \mathrm{PM}_{2.5}$ \\
\hline Average $^{a}$ & 0.60 & 0.48 & 0.35 & 0.72 & 0.63 & 0.37 & 0.29 & 0.79 \\
\hline Max & 0.91 & 0.82 & 0.67 & 0.92 & 0.79 & 0.46 & 0.37 & 0.88 \\
\hline Min & 0.35 & 0.21 & 0.16 & 0.53 & 0.32 & 0.23 & 0.20 & 0.63 \\
\hline
\end{tabular}

${ }^{\mathrm{a}}$ Arithmetic average.

For $\mathrm{PM}_{2.5}$, the maximum AQI value was 178 , and the index values tend to be higher than those for $\mathrm{PM}_{10}$. The AQI values for $\mathrm{PM}_{2.5}$ generally range from 50 to 150 , whereas the AQI values for $\mathrm{PM}_{10}$ in most of days were less than 100. These results imply that the corresponding $\mathrm{PM}_{2.5}$ AQIs were relatively high and this pollutant poses higher health hazards to the population as compared with $\mathrm{PM}_{10}$. As it can be seen (Figure 5), AQI values decrease strongly in spring and result in health effects of PM decline in this season.

These values for $\mathrm{PM}_{2.5}$ result from the higher contribution of the fine fraction to the $\mathrm{PM}_{10}$ mass. This can be due to high portion of $\mathrm{PM}_{2.5}$ results from use of fuel for heating devices in homes and traffic-related combustion processes during cold season in urban.

Based on the measured TSP, $\mathrm{PM}_{10}$ and $\mathrm{PM}_{2.5}$ concentrations over the study period, some estimated short term health effects of PM are given in Table 4. Relative risk (RR) gives the increase in the probability of the adverse effect associated with a given change in the exposure levels, and comes from time-series studies, where dayto-day changes in air pollutants over long periods were related to the daily mortality, hospital admissions and other public health indicators [11]. Table 4 shows the values of $R R$ used in the present assessment together with total mortality, cardiovascular mortality, respiratory mortality, and some other health effects.

The total mortalities associated with TSP, $\mathrm{PM}_{10}$ and $\mathrm{PM}_{2.5}$ concentrations are 327, 363 and 360, respectively. Also the cardiovascular mortality for TSP and $\mathrm{PM}_{10}$ are 202 and 227, respectively. According to the respiratory mortality associated with the TSP and $\mathrm{PM}_{10}, 99$ and 67, respectively, it's clear that cardiovascular mortality has the main rate in total mortality resulted from PM.

It should be noted that the current study did not include an epidemiological investigation. Therefore, the estimates of health effects were based on the relative risks and the baseline incidences calculated by AirQ2.2.3 software. Since there was not any study to calculate the $R R$ values in Iran, we used the values of $R R$ from the above mentioned studies and also the study of Naddafi et al. [6]. Because the characteristics of the target population differed from those of the populations investigated in these epidemiological studies, this approach adds considerable uncertainty to the estimates calculated by the software. However, this information could be highly useful because they provide valuable information about the importance of air pollution and the substantial impacts of PM on the society for policymakers.

\section{Conclusion}

The present study was carried out to determine the mass levels of TSP, $\mathrm{PM}_{10}, \mathrm{PM}_{2.5}$, and $\mathrm{PM}_{1}$ and also seasonal variations of water soluble ionic species associated with TSP and $\mathrm{PM}_{10}$ particles in urban and industrial suburban sites of Tabriz. The annual average concentrations of TSP, $\mathrm{PM}_{10}, \mathrm{PM}_{2.5}$, and $\mathrm{PM}_{1}$ in the industrial suburban were higher than urban sites. In the urban sampling stations, the 24-h mean concentrations of $\mathrm{PM}_{10}$ and $\mathrm{PM}_{2.5}$, exceeded WHO and national air quality level in $72 \%$ and $71 \%$ of the time, respectively.

Sometimes local dust occurred in urban and suburban, but dust storm was not observed in this city during the period of present study.
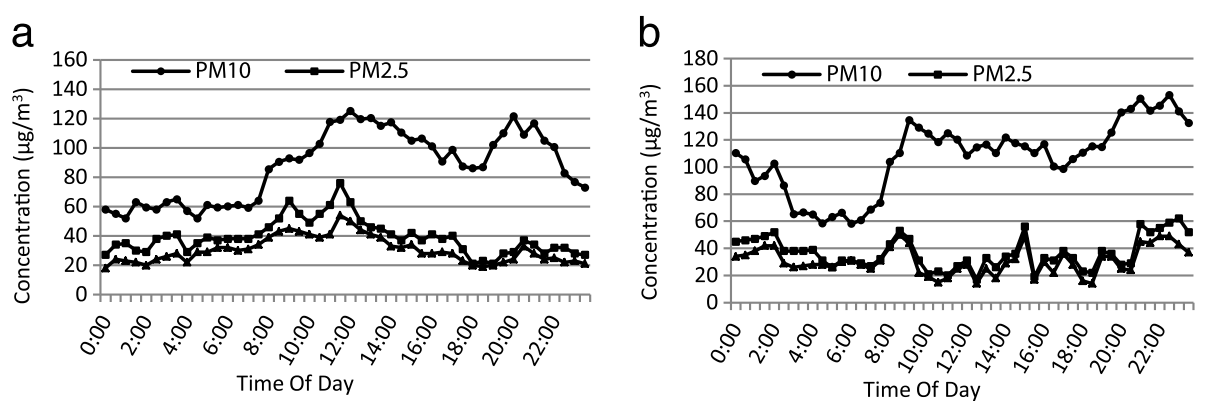

Figure 4 Average hourly variations of $\mathrm{PM}_{10}, \mathrm{PM}_{2.5}$ and $\mathrm{PM1}$ in the urban (a) and industrial suburban (b). 


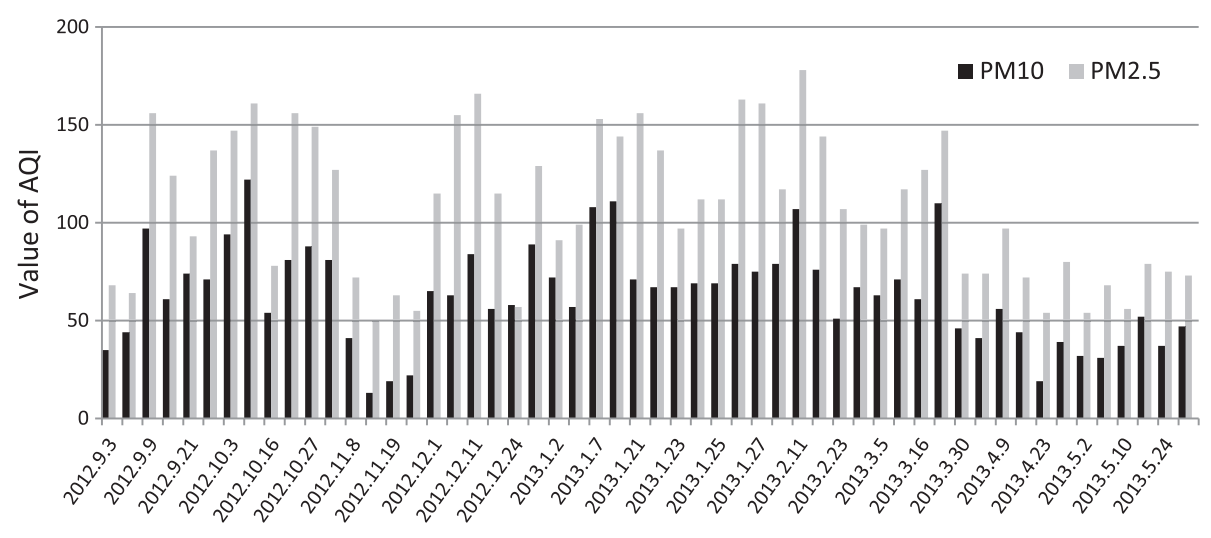

Figure 5 AQI values in Tabriz for $\mathrm{PM}_{10}$ and $\mathrm{PM}_{2.5}$ during all the days when measurements were made.

The $\mathrm{PM}_{10} / \mathrm{TSP}$ ratios, for the whole study period, were ranged from 0.35 to 0.91 for urban and from 0.32 to 0.79 for suburban sites, respectively.

In this study we have estimated the impact of PM on human health with AirQ software developed by WHO. Based on the calculated effects, the total mortalities associated with the TSP, $\mathrm{PM}_{10}$ and $\mathrm{PM}_{2.5}$ concentrations were 327,363 and 360 , respectively. According to the cardiovascular and respiratory mortalities associated with TSP and $\mathrm{PM}_{10}$, it might conclude that the cardiovascular mortality has the main role in the total mortality resulted from PM.

Table 4 Estimated attributable proportion (AP) expressed as percentage and number of excess cases in a year due to short-term exposure to TSP, $\mathrm{PM}_{10}$ and $\mathrm{PM}_{2.5}$

\begin{tabular}{|c|c|c|c|c|}
\hline & $\begin{array}{c}\text { Relative risk } \\
\text { Mean* }\end{array}$ & $\begin{array}{c}\text { Baseline } \\
\text { incidences }\end{array}$ & $\begin{array}{c}\text { Estimated } \\
\text { attributable } \\
\text { portion } \\
\text { percentage* }\end{array}$ & $\begin{array}{c}\text { Estimated } \\
\text { number of } \\
\text { excess cases* }\end{array}$ \\
\hline & \multicolumn{4}{|c|}{ TSP } \\
\hline Total mortality & $1.003(1.002-1.007)$ & 543.5 & $3.9(2.6-8.6)$ & $327(221-725)$ \\
\hline Cardiovascular mortality & $1.002(1-1.006)$ & 497 & $2.63(0-7.5)$ & $202(0-575)$ \\
\hline Respiratory mortality & $1.008(1.004-1.018)$ & 66 & 9.7(5.1-19.5) & $99(52-199)$ \\
\hline Hospital admissions for respiratory diseases & -—- & -—- & -—- & -—- \\
\hline Hospital admissions for chronic obstructive pulmonary disease & $1.0044(1-1.0094)$ & 101.4 & $5.6(0-11.3)$ & $88(0-176)$ \\
\hline \multirow[t]{2}{*}{ Hospital admissions for cerebrovascular disease } & -—- & -—- & -—- & -—- \\
\hline & \multicolumn{4}{|c|}{$\mathrm{PM}_{10}$} \\
\hline Total mortality & $1.006(1.004-1.008)$ & 543.5 & $4.3(2.9-5.7)$ & $363(246-478)$ \\
\hline Cardiovascular mortality & $1.009(1.005-1.013)$ & 231 & $6.4(3.6-8.9)$ & 227(130-319) \\
\hline Respiratory mortality & $1.013(1.005-1.02)$ & 48.4 & $8.9(3.6-13)$ & $67(27-98)$ \\
\hline Hospital admissions for respiratory diseases & $1.008(1.0048-1.0112)$ & 1260 & $5.7(3.5-7.8)$ & 1107(680-1515) \\
\hline Hospital admissions for chronic obstructive pulmonary disease & -—- & -—- & -—- & -—- \\
\hline \multirow[t]{2}{*}{ Hospital admissions for cerebrovascular disease } & $1.009(1.006-1.013)$ & 436 & $6.3(4.3-8.9)$ & $428(291-601)$ \\
\hline & \multicolumn{4}{|c|}{$\mathrm{PM}_{2.5}$} \\
\hline Total mortality & $1.015(1.011-1.019)$ & 543.5 & $4.3(3.2-5.4)$ & $360(267-450)$ \\
\hline Cardiovascular mortality & -1 & -—- & -—— & -—- \\
\hline Respiratory mortality & - - & -一 & -—- & - - \\
\hline Hospital admissions for respiratory diseases & -- & -—- & -—- & -—- \\
\hline Hospital admissions for chronic obstructive pulmonary disease & -—- & -- & -— & -— \\
\hline Hospital admissions for cerebrovascular disease & - - & -—- & -—- & -—- \\
\hline
\end{tabular}

*Mean (lower-upper). 


\section{Competing interests}

The authors declare that they have no competing interests.

\section{Authors' contributions}

AG was the main investigator, designed and performed the study and drafted the manuscript. AHM supervised the study. RN, SN, MY, HT, and NR were advisors of the study. SF and ShN helped in the PM analysis. All authors read and approved the final manuscript.

\section{Acknowledgments}

The authors would like to acknowledge the Health faculty of Tabriz Medical Science university and Tabriz petrochemical plant for providing us with sampling locations. This work was funded by the Institute for Environmental Research (IER) of Tehran University of Medical Sciences (grant number 92-01-46-21257).

\section{Author details}

'Department of Environmental Health Engineering, School of Public Health, Tehran University of Medical Sciences, Tehran, Iran. ${ }^{2}$ Department of Environmental Health Engineering, School of Public Health, Tabriz University of Medical Sciences, Tabriz, Iran. ${ }^{3}$ Center for Water Quality Research (CAPR), Institute for Environmental Research (IER), Tehran University of Medical Sciences, Tehran, Iran. ${ }^{4}$ Center for Air Pollution Research (CAPR), Institute for Environmental Research (IER), Tehran University of Medical Sciences, Tehran, Iran. ${ }^{5}$ Center for Solid Waste Research (CAPR), Institute for Environmental Research, Tehran University of Medical Sciences, Tehran, Iran. ${ }^{6}$ National Institute of Health Research, Tehran University of Medical Sciences, Tehran, Iran.

Received: 12 August 2013 Accepted: 19 November 2013 Published: 10 January 2014

\section{References}

1. Nicolas J, Chiari M, Crespo J, Orellana IG, Lucarelli F, Nava S, Pastor C, Yubero E: Quantification of Saharan and local dust impact in an arid Mediterranean area by the positive matrix factorization (PMF) technique. Atmos Environ 2008, 42:8872-8882.

2. Deshmukh D, Tsai Y, Zarmpas P: Characteristics and sources of watersoluble ionic species associated with PM10 particles in the ambient air of central India. Bull Environ Contam Toxicol 2012, 89:1091-1097.

3. Sun Y, Zhuang G, Wang Y, Han L, Guo J, Dan M, Zhang W, Wang Z, Hao Z: The air-borne particulate pollution in Beijing-concentration, composition, distribution and sources. Atmos Environ 2004, 38:5991-6004.

4. Singh R, Sharma BS: Composition, seasonal variation, and sources of PM10 from world heritage site Taj Mahal, Agra. Environ Monit Assess 2012, 184:5945-5956.

5. Lin C-W, Yeh J-F, Kao T-C: Source characterization of total suspended particulate matter near a riverbed in Central Taiwan. J Hazard Mater 2008, 157:418-422.

6. Naddafi K, Hassanvand MS, Yunesian M, Momeniha F, Nabizadeh R, Faridi S, Gholampour A: Health impact assessment of air pollution in megacity of Tehran, Iran. Iranian Journal of Environmental Health Science \& Engineering 2012, 9:1-7.

7. Pope CA III, Burnett RT, Thun MJ, Calle EE, Krewski D, Ito K, Thurston GD: Lung cancer, cardiopulmonary mortality, and long-term exposure to fine particulate air pollution. JAMA 2002, 287:1132-1141.

8. Dockery DW, Pope CA: Acute respiratory effects of particulate air pollution. Annu Rev Public Health 1994, 15:107-132.

9. Cohen AJ, Anderson HR, Ostro B, Pandey KD, Krzyzanowski M, KÃ1/4nzli N, Gutschmidt K, Pope CA III, Romieu I, Samet JM: Urban air pollution. Comparative quantification of health risks 2004, 2:1353-1433.

10. Schwartz J: Air pollution and daily mortality: a review and meta analysis. Environ Res 1994, 64:36-52.

11. Fattore E, Paiano V, Borgini A, Tittarelli A, Bertoldi M, Crosignani P, Fanelli R: Human health risk in relation to air quality in two municipalities in an industrialized area of Northern Italy. Environ Res 2011, 111:1321-1327.

12. Arhami M, Minguillón M, Polidori A, Schauer J, Delfino R, Sioutas C: Organic compound characterization and source apportionment of indoor and outdoor quasi-ultrafine particulate matter in retirement homes of the Los Angeles Basin. Indoor Air 2010, 20:17-30.
13. Brunekreef B, Forsberg B: Epidemiological evidence of effects of coarse airborne particles on health. Eur Respir J 2005, 26:309-318.

14. Bell ML: Assessment of the health impacts of particulate matter characteristics. Res Rep Health Eff Inst 2012, 161:5-38.

15. Pope CA III, Ezzati M, Dockery DW: Fine-particulate air pollution and life expectancy in the United States. N Engl J Med 2009, 360:376-386.

16. Cao J, Yang C, Li J, Chen R, Chen B, Gu D, Kan H: Association between long-term exposure to outdoor air pollution and mortality in China: a cohort study. J Hazard Mater 2011, 186:1594-1600.

17. Peng RD, Chang HH, Bell ML, McDermott A, Zeger SL, Samet JM, Dominici F: Coarse particulate matter air pollution and hospital admissions for cardiovascular and respiratory diseases among Medicare patients. JAMA 2008, 299:2172-2179.

18. Shahsavani A, Naddafi K, Jafarzade Haghighifard N, Mesdaghinia A, Yunesian M, Nabizadeh R, Arahami M, Sowlat M, Yarahmadi M, Saki H: The evaluation of PM10, PM 2.5, and PM1 concentrations during the middle eastern dust (MED) events in Ahvaz, Iran, from april through september 2010. $J$ Arid Environ 2012, 77:72-83.

19. Givehchi R, Arhami M, Tajishy M: Contribution of the middle eastern dust source areas to PM10 levels in urban receptors: case study of Tehran, Iran. Atmos Environ 2013, 75:287-295.

20. Hojati S, Khademi H, Faz Cano A, Landi A: Characteristics of dust deposited along a transect between central Iran and the Zagros mountains. CATENA 2012, 88:27-36.

21. Masoumi A, Khalesifard HR, Bayat A, Moradhaseli R: Retrieval of aerosol optical and physical properties from ground-based measurements for Zanjan, a city in northwest Iran. Atmos Res 2012, 120-121:343-355.

22. Rashki A, Eriksson PG, Rautenbach CJW, Kaskaoutis DG, Grote W, Dykstra J: Assessment of chemical and mineralogical characteristics of airborne dust in the Sistan region, Iran. Chemosphere 2012, 90:227-236.

23. Zarasvandi A, Carranza EJM, Moore F, Rastmanesh F: Spatio-temporal occurrences and mineralogical, geochemical characteristics of airborne dusts in Khuzestan province (southwestern Iran). J Geochem Explor 2011, 111:138-151.

24. Sanobari F, Banisaeid S: Determination of atmospheric particulate matter and heavy metals in air of Tabriz City, Iran. Asian J Chem 2007, 19:4143-4150.

25. Yearbook IS: Statistical Center of Iran. Tehran, Iran; 2013.

26. U.S.EPA: Federal register: National Ambient Air Quality Standards for Particulate Matter; Final Rule. 2013:78.

27. U.S.EPA: Guideline: Monitoring site selection. 1998. EPA Report No.: EPA454/R-98-003.

28. National Climatic Data Center site. [http://www7.ncdc.noaa.gov/CDO/ cdoselect.cmd]

29. WHO: Air Quality Health Impact Assessment Software AirQ 2.2. 2004

30. Krzyzanowski M: Methods for assessing the extent of exposure and effects of air pollution. Occup Environ Med 1997, 54:145-151.

31. Chen B, Hong C, Kan H: Exposures and health outcomes from outdoor air pollutants in China. Toxicology 2004, 198:291-300.

32. Goldberg MS, Burnett RT, Valois M-F, Flegel K, Bailar lii JC, Brook J, Vincent R, Radon K: Associations between ambient air pollution and daily mortality among persons with congestive heart failure. Environ Res 2003, 91:8-20.

33. Anderson H, Atkinson RW, Peacock J, Marston L, Konstantinou K: Meta-analysis of time-series studies and panel studies of particulate matter (PM) and ozone (O3). Report of a WHO Task Group Copenhagen: World Health Organization; 2004.

34. Breitner S, Stölzel M, Cyrys J, Pitz M, Wölke G, Kreyling W, Küchenhoff H, Heinrich J, Wichmann H-E, Peters A: Short-term mortality rates during a decade of improved air quality in Erfurt, Germany. Environ Health Perspect 2009, 117:448.

35. Europe WHO ROf: World Health Organization Regional Office for Europe Copenhagen. Air Quality Guidelines for Europe. 2nd edition. WHO Regional Publications; 2000.

36. Europe WHOROf: Air Quality Guidelines: Global Update 2005: Particulate Matter, Ozone, Nitrogen Dioxide and Sulfur Dioxide. World Health Organization; 2006. Available at: whqlibdoc.who.int/hq/2006/ WHO_SDE_PHE_OEH_06.02_eng.pdf. Accessed 22 July 2013.

37. Wang X, Dong Z, Zhang J, Liu L: Modern dust storms in China: an overview. J Arid Environ 2004, 58:559-574.

38. Hoffmann C, Funk R, Wieland R, Li Y, Sommer M: Effects of grazing and topography on dust flux and deposition in the Xilingele grassland, Inner Mongolia. J Arid Environ 2008, 72:792-807. 
39. Chelani A, Gajghate D, ChalapatiRao C, Devotta S: Particle size distribution in ambient air of Delhi and its statistical analysis. Bull Environ Contam Toxicol 2010, 85:22-27.

40. Monn C, Braendli O, Schaeppi G, Schindler C, Ackermann-Liebrich U, Leuenberger P: Particulate matter PM10 and total suspended particulates (TSP) in urban, rural and alpine air in Switzerland. Atmos Environ 1995, 29:2565-2573.

41. Aldabe J, Elustondo D, Santamara C, Lasheras E, Pandolfi M, Alastuey A, Querol X, Santamara JM: Chemical characterisation and source apportionment of PM2.5 and PM10 at rural, urban and traffic sites in Navarra (North of Spain). Atmos Res 2011, 102:191-205.

42. United States. Environmental Protection Agency. Office of Air Quality Planning and Standards: Guidelines for the reporting of daily air quality-the air quality index (AQI). [Research Triangle Park, N.C.]: United States Environmental Protection Agency, Office of Air Quality Planning and Standards; 2006

doi:10.1186/2052-336X-12-27

Cite this article as: Gholampour et al:: Exposure and health impacts of outdoor particulate matter in two urban and industrialized area of Tabriz, Iran. Journal of Environmental Health Sciences \& Engineering 2014 12:27.

\section{Submit your next manuscript to BioMed Central and take full advantage of:}

- Convenient online submission

- Thorough peer review

- No space constraints or color figure charges

- Immediate publication on acceptance

- Inclusion in PubMed, CAS, Scopus and Google Scholar

- Research which is freely available for redistribution 